\title{
Exploring EFL teacher's role in a smart learning environment - review study
}

\author{
Dinara G. Vasbieva - Natalia L. Sokolova - Alfiya R. Masalimova - \\ Vladimir M. Shinkaruk - Yuliya L. Kiva-Khamzina
}

DOI: 10.18355/XL.2018.11.02.21

\begin{abstract}
The paper investigates EFL teacher's role in a smart learning environment (SLE) which uses education technologies to provide essential tools for teachers to personalize teaching, adjust teaching and assessment, and create authentic learning environments for students. SLEs are aimed at using technology to bring real life experiences into the classroom to engage students, and prepare them for life-long education and future careers in a way that traditional practices often fail to do. The study was designed to review a vast amount of literature devoted to the potential of SLEs and teacher's role in these learning settings and propose a model for EFL teacher's multiple roles in SLE.
\end{abstract}

Key words: smart learning environment, information and communication technology, student-centered approach, teacher-centered approach, EFL teacher's role

\section{Introduction}

Information and communication technology (ICT) has become an integral part of our lives and has practically penetrated into all spheres of human communication. New technology removes barriers faster than it could be imagined. The development of technology enables new work practices, greater mobility, and virtual working. Its availability and application provide new opportunities and pose new challenges that need to be addressed. Over recent decades the widespread growth of media and information technologies and their effect on all fields of human activities have undoubtedly brought the remarkable changes in the educational system that puts an emphasis on a student's independent creative potential, integration of various teaching plans, or diversity of teaching methods and strategies. Clearly, integration of ICT in today's classrooms and technologically savvy students have enhanced the promotion of 21 st century skills, such as interpersonal skills, interactive communication skills, technology literacy skills as well as language skills related to workplace needs. Thus, the traditional role of a teacher is changing. Nonetheless, the teacher's role must stem deliberately from the established learning aims and objectives, the curriculum and agreed-upon learning principles. Besides, teachers still play a decisive role in using different teaching approaches and strategies, and defining whether and how to apply technology in a smart learning environment (SLE). It is becoming increasingly important for such SLEs to be implemented in higher educational institutions in order to provide students with a relevant and engaging learning experience. A SLE is one that features the use of innovative technologies and elements that allow greater flexibility, adaptation, engagement, and feedback for the learner (Spector, 2014). Such technological advancements are potentially ground-breaking for the way teachers do their jobs and interact with students, paving the way for more student-centred approach adapted to the needs and expectations of the specific students. The purpose of this article is an attempt to investigate the EFL teacher's role in the smart learning environment. 


\section{Literature Review}

\subsection{Smart Learning Environment as a New Strategy for the Development of Education}

Foreign Language studies differ from many other academic disciplines in the presence of practical skills and theoretical knowledge among learners, which affects both facilities and software used in teaching, and the pedagogical and instructional techniques of EFL teaching. Acquiring new skills, new "literacy" (technical, critical, linguistic and cultural) plays a very important role in the adoption and use of ICT in EFL teaching. Successful integration and use of new technologies are closely linked and directly dependent on the teachers' training, special efforts being required to create teachers' professional development programme, to demonstrate the benefits of using ICT in the educational process, and sometimes to overcome the resistance to their use (Gerasimenko et al., 2012).

However, the presence of new technologies does not lead to an automatic change in the "culture" of teaching itself, they only provide opportunities for its transformation. The teachers' attitude towards new technologies and the concepts of their use and organization of teaching determine whether the desired results will be achieved or not, and whether a change in the "culture" of teaching itself is possible. It is common to observe that ICT by itself is simply part of the whole set of the resources and a means available for learning and education: the important question is not whether it is used but how it is used (http://www.oecd.org/site/educeri21st/40554299.pdf). Therefore, in order to use ICT rationally and harmlessly, proper qualifications and a suitable high level of technical culture are required (Musioł, 2017).

ICT provides the foundation for the systemic transformation of a smart learning environment. ICT delivers the tools needed to enhance teaching and learning and support student-centered learning environments. In his book "Good to Great", J. Collins (2001) stresses that technology is an accelerator.

In most studies different scholars put forward their understandings of SLE from different perspectives.

M.D. Merrill (2013) argues that SLE is a learning setting that is effective, efficient and engaging. The student is always put at the centre of SLE, its main purpose being to guide learners to become self-directed, self-motivated and self-learning. Moreover, learners study at their own pace and are able to access the personalized learning content according to their personal difference (Kim, Cho \& Lee, 2013).

R. Huang, J. Yang and L. Zheng (2013) define a smart learning environment as "the learning place or an activity space that can sense learning scenarios, identify the characteristics of learners, provide appropriate learning resources and convenient interactive tools, automatically record the learning process and evaluate learning outcomes in order to promote effective learning".

Smart learning environments are defined by R. Koper (2014) to refer to physical environments that are enriched with digital, context-aware and adaptive devices, to promote better and faster learning.

In a smart learning environment, learning can take place anywhere, anytime, at any pace. Today's schools must promote the learning environment which ensures all the necessary learning guidance, hints, supportive tools, or learning suggestions to students (Hwang, 2014). G.J. Hwang (2014) claims that "a smart learning environment can be regarded as the technology-supported learning environments that make adaptations and provide appropriate support (e.g., guidance, feedback, hints or tools) in the right places and at the right time based on individual learners' needs, which might be determined via analysing their learning behaviours, performance and the online and real-world contexts in which they are situated". Apart from that the smart learning environment is identified as "minimally context-aware (i.e., only the online and real-world states of learners are considered as the context of learning), minimally adaptive (i.e., the adaptivity with respect to emotional states, cognitive 
capacity, motivation, and socio-economic factors are not considered), and minimally personalized (i.e., pedagogy-oriented guidance is not considered)".

According to Z.T. Zhu, M.H. YU and P. Riezebos (2016), "the objective of smart education is to improve learners' quality of lifelong learning. It focuses on contextual, personalized and seamless learning to promote learners' emerging intelligence and facilitate their problem-solving ability in smart environments".

B. Gros (2016) suggests two different types of technologies: smart devices and intelligent technologies that smart learning is founded on. "Smart devices refer to artefacts that exhibit some properties of ubiquitous computing, including (although not necessarily) artificial intelligence; for instance, the Internet of things, wearable technology in the form of an accessory such as glasses, a backpack, or even clothing". Intelligent technologies refer to learning analytics, cloud computing and AI capabilities, and are vital in capturing valuable learning data that can effectively enhance the development of personalized and adaptive learning (Mayer, Schönberger, Cukier, 2013; Picciano, 2012).

Based on the above definitions to SLE, successful management in the teaching process in SLE should consider the following teachers' attributes (Table 1).

Table 1: Attributes of EFL teachers working in SLE

\begin{tabular}{|l|l|}
\hline \multicolumn{1}{|c|}{ Attributes } & \multicolumn{1}{|c|}{ Meaning } \\
\hline Adaptivity & $\begin{array}{l}\text { being able to adjust to different learning } \\
\text { situations, different students' learning styles } \\
\text { and different technology tools }\end{array}$ \\
\hline Flexibility & $\begin{array}{l}\text { being able to easily change and adjust the } \\
\text { learning objectives teaching methods, } \\
\text { educational content and learning materials } \\
\text { according to students' needs }\end{array}$ \\
\hline Reflectiveness & $\begin{array}{l}\text { being able to recognize successes and failures } \\
\text { and learn from mistakes }\end{array}$ \\
\hline Engagement & $\begin{array}{l}\text { the willingness to collaborate with and learn } \\
\text { from others }\end{array}$ \\
\hline Efficiency & $\begin{array}{l}\text { the ability to be effective without exorbitant } \\
\text { costs and extreme effort }\end{array}$ \\
\hline Effectiveness & $\begin{array}{l}\text { being able to produce acceptable and desirable } \\
\text { outcomes for students to satisfy their needs; } \\
\text { being able to achieve recognized goals and } \\
\text { objectives }\end{array}$ \\
\hline
\end{tabular}

\subsection{Teacher's Role in a SLE}

As it can be seen much work on the potential of smart learning environments has been carried out (Huang, Yang \& Zheng, 2013; Hwang, 2014; Gros, 2016), however there are still few studies of the teacher's role in these learning settings as a whole and in particular EFL teacher's (Klimova, 2017).

There is a vast amount of literature on the instructor's role in online or electronic learning. D. Laurillard (2002) was the first to propose the transformation of the teacher's role from a knowledge source to something that is more of a facilitator as a conversational framework for the evolution of learning. D. Laurillard (2002) believes that this framework can be applied to the evaluation of technologies in learning. The use of teaching and learning technologies should be aimed at ensuring studentcentered situations where instructors facilitate access to content in a horizontal, sharing environment where students learn as much from the course theoretical content as from their peers. 
Another investigation conducted by A. Sfard (1998) examined faculty's changing role from a knowledge holder into a facilitator through the use of ICT. A set of roles have been suggested from the perspectives of two various models. For instance, in the acquisition model, the instructor's role is delivering, suggesting, and clarifying knowledge and concepts. In the participation model, instructors are more popularly known as facilitators, mentors, expert participants, and guardians of practice/discourse. The instructor becomes a member of a community of practice, learning from the community but also contributing to it. Individual thinking and construction of meaning are the core of the collaboration framework. Teaching can be described as student-centered, more tentative, flexible, and experimental. In this context, learners are likely to improve learning through their interaction (Burkle, 2003; Perry, 2003).

In their studies D. Light and E. Pierson (2012a; 2012b) have focused on major changes in teacher's attitudes to teaching, their knowledge and behavior, as well as a shift in beliefs about how students learn, new teaching strategies, changes in students' learning activities and changes in how ICT was used to promote learning, including an increase in classroom management and access to educational resources that resulted in increased time spent on task.

It is known that teachers play a critical role in determining whether and how to apply technologies in their classrooms (Lin, Liu \& Kinshuk, 2015). Working at SMARTtechnologies, the teacher's (tutor's) role as an organizer and coordinator of the learning process is especially important, as they are given a free hand to more flexibly guide the educational process in accordance with the individual capabilities of each student (Nazarova, 2012).

R. Huang, J. Yang and L. Zheng (2013) state that the role of teachers in SLE must change from that of an instructor to that of a facilitator, and the community of teachers is leading elements of SLEs, which should support the faculty development. This point of view deserved A. Sahu's (2013) backing, who claimed that in smart class, the teacher takes the part of a facilitator in learning. Smart learning makes it easy for students to learn with multimedia, computers and the Internet (Galushkin, 2015a,b). The teacher has to facilitate learning and to teach students how to learn from multimedia, internet and the other innovative means of learning. Teachers should be an expert to smart learning and smart education. "Greater demands are placed on teachers in terms of quality of instruction, curricular work, but also autonomy and creativity. Expert teachers generally perceive these extra demands positively, i.e. as challenging and stimulating» (Uliccna et al., 2016). He/she has to know how to use computers and Internet in classroom teaching/learning. Teachers have to know the innovative use of smart and innovative teaching/learning (Sahu, 2013).

Clearly, the most important role of the online instructor is to model effective teaching and accept "the responsibility of keeping discussions track, contributing special knowledge and insights, weaving together various discussion threads and course components, and maintaining group harmony" (Rohfeld, Hiemstra, 1995).

\section{Methodology}

The study has been undertaken as part of the methodology of pedagogy, methodology, and fundamental pedagogical works considering use of ICT in teaching process, a smart learning environment and teacher's roles in online and electronic learning as well as smart classrooms.

\section{Results and Discussion}

The main reasons for using innovative computer-based technologies by EFL teachers are as follows (Gerasimenko et al., 2012):

- teaching in an authentic language environment 
- access to extensive sources of information and various language options

- opportunities to communicate with the outside world

- a learner-centered approach to teaching

- development of the student's ability to work independently

- greater diversity of educational content

- new conditions for students' self-study and creation of individual learning trajectories

- joint planning and organising a course of study, which allows students to influence the choice of educational content and "follow the new content at their own pace" (Beronja, Kozina, 2017)

- elimination of the limitations inherent to the traditional methods of teaching, leading to learning/teaching beyond the classroom

- promotion of student-student and student-teacher communication via the Internet.

To effectively use ICT in teaching process, EFL teachers should be aware of each student's learning difficulties, make a deliberate decision when choosing a technology, check the reliability of the information content offered, develop effective methods of searching and be able to conduct computer-based research, use the standard software confidently and competently, critically evaluate and select the obtained information.

Table 2 shows how the use of ICT has changed the traditional approaches to teaching and learning.

Table 2: Transformation of teaching practices: traditional learning settings vs technology-enhanced learning environment

\begin{tabular}{|l|l|}
\hline Traditional approach & Technology-mediated classroom \\
\hline $\begin{array}{l}\text { Teacher-centered classroom } \\
\text { management }\end{array}$ & $\begin{array}{l}\text { Student-centered approach adapted to the } \\
\text { needs and expectations of the specific } \\
\text { students }\end{array}$ \\
\hline $\begin{array}{l}\text { One-size-fits-all approach to } \\
\text { teaching/learning }\end{array}$ & $\begin{array}{l}\text { Instruction tailored to individual } \\
\text { student's needs and interests }\end{array}$ \\
\hline One pace for all students & $\begin{array}{l}\text { Flexible pacing (students are able to self- } \\
\text { pace and self-direct their learning } \\
\text { within a class period, week, unit, etc.) }\end{array}$ \\
\hline Classroom-based course & $\begin{array}{l}\text { Open and distributed learning in } \\
\text { multiple places and spaces }\end{array}$ \\
\hline In-class learning & Anytime learning \\
\hline Memorization and recitation of facts & $\begin{array}{l}\text { Critical thinking in real-life, authentic } \\
\text { situations }\end{array}$ \\
\hline $\begin{array}{l}\text { The teacher as information giver; } \\
\text { knowledge flows only one way } \\
\text { from teacher to student }\end{array}$ & $\begin{array}{l}\text { Collaboration and a dialogue among } \\
\text { students and between teachers and } \\
\text { students }\end{array}$ \\
\hline Traditional print books & $\begin{array}{l}\text { Interactive and regularly updated } \\
\text { dynamic content of digital textbooks } \\
\text { encouraging real-time exploration } \\
\text { through connected web channels } \\
\text { and resources }\end{array}$ \\
\hline
\end{tabular}

Source: Authors' own processing

We proposed a model for EFL teacher's roles in a smart learning environment based on Smart Learning model for educational transformation by J.K. Price (2015) research into teacher's roles in computer conferencing. 
The model suggested by J.K. Price (2015) 'was developed to reflect evidence-based best practices that have emerged from Intel's collaborations with school systems and governments in more than 100 countries to address the practical approaches to deep, large-scale, systemic change with ICT, to create sustainable improvements in student learning'.

Our model for EFL teacher's roles in a smart learning environment owes a lot to the one proposed R.W. Rohfeld and R. Hiemstra (1995), who identified teacher's roles in online tutoring:

- pedagogical (intellectual) role which involves that of a moderator/tutor as an educational facilitator. The moderator asks students questions and sounds out their answers, which puts discussions on critical concepts, principles and skills.

- social role that aims at creating a friendly learning environment "promoting human relationships, developing group cohesiveness, maintaining the group as a unit, and in other ways helping members to work together in a mutual cause".

- managerial role which involves setting the agenda for the conference: the objectives of the discussion, the timetable, procedural rules and decision-making norms.

- technical role which involves developing IT competence; becoming familiar with ICT and software; being able to competently use some widespread mobile and software apps, to identify some technical difficulties the learners face, make the technology transparent, to choose relevant technologies for teaching and to do research with the help of ICT.

Table 3 explains each EFL teacher's role in smart learning environments.

\section{Table 3: Model for EFL teacher's roles in SLE}

\begin{tabular}{|c|l|}
\hline EFL teacher's role & \multicolumn{1}{c|}{ Description } \\
\hline Facilitator & $\begin{array}{l}\text { The role involves facilitating access to content through the use } \\
\text { of information technologies. } \\
\text { Certainly, some of the most important roles of online } \\
\text { discussion moderator/tutor revolves around their duties as an } \\
\text { educational facilitator. The moderator uses questions and } \\
\text { probes for student responses that focus discussions on critical } \\
\text { concepts, principles and skills. }\end{array}$ \\
\hline Collaborator/mentor & $\begin{array}{l}\text { Teacher's role as collaborators and mentors with students } \\
\text { engaging in real world, possibly entrepreneurial, activities } \\
\text { would help students develop actual marketable skills and } \\
\text { could potentially provide a new and much needed revenue } \\
\text { stream for universities. }\end{array}$ \\
\hline Technician & $\begin{array}{l}\text { This role involves making learners comfortable with the } \\
\text { system and the software; developing IT competence; } \\
\text { becoming familiar with ICT and software; being able to } \\
\text { confidently and competently use some standard software and } \\
\text { common mobile apps, to identify some technical difficulties } \\
\text { the learners face, to make the technology transparent, to } \\
\text { choose relevant technologies for teaching, to critically } \\
\text { evaluate and select information obtained from the Internet } \\
\text { resources and to do computer-based research. }\end{array}$ \\
He/she is in charge of: \\
$\bullet \begin{array}{l}\text { providing students with curriculum activities that } \\
\text { maximize the potential of technology } \\
\text { developing learning designs based on new innovative } \\
\text { technologies }\end{array}$ \\
\hline
\end{tabular}




\begin{tabular}{|c|c|}
\hline & $\begin{array}{l}\text { - devising different assessment tools that can be } \\
\text { incorporated into the learning process. }\end{array}$ \\
\hline Developer & $\begin{array}{l}\text { Educators, like students, thrive when given the proper tools, } \\
\text { training, and inspiration. } \\
\text { This role involves developing resources that make the most of } \\
\text { modern, personalized learning environments and technology } \\
\text { tools enable effective use of today's technologies. }\end{array}$ \\
\hline Manager & $\begin{array}{l}\text { The role involves: } \\
\text { - } \text { being expertly conversant with the changes technologies } \\
\text { are bringing into the classrooms and provide appropriate } \\
\text { support } \\
\text { - making wise decisions with regard to technology and } \\
\text { resources as long-term sustainability is important. This } \\
\text { will be measured by sustained 'value and drive' on } \\
\text { student performance. }\end{array}$ \\
\hline $\begin{array}{l}\text { Researcher and } \\
\text { Evaluator }\end{array}$ & $\begin{array}{l}\text { The roles entail: } \\
\text { - } \\
\text { M\&Entinuous evaluation and improvement using refined } \\
\text { - } \text { research on more futuristic SLEs driven by data and } \\
\text { analytics. }\end{array}$ \\
\hline
\end{tabular}

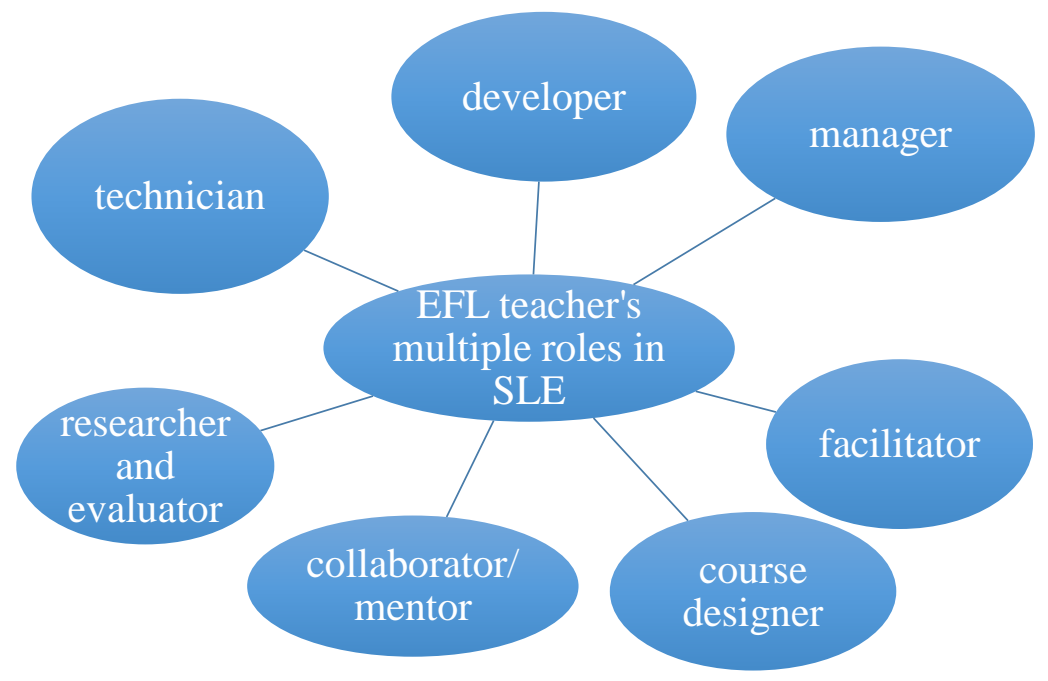

Figure 1: EFL teacher's multiple roles in SLE

\section{Conclusion}

Thus the significance of this study stems from the idea that knowing EFL teacher's roles in SLEs help ensure that high educational institutions can effectively transform their traditional classrooms into SLEs. Such smart classrooms are known to use education technologies to provide essential tools for teachers to personalize teaching, adjust teaching and assessment, and create authentic learning environments for students. SLEs are aimed at using technology to bring real life experiences into the classroom to engage students, and prepare them for life-long education and future 
careers in a way that traditional practices often fail to do. However, for sustained transformation, much more than the technology must be considered. It worth taking into account Intel officers and Sr. Management comment: "Computers aren't magic, teachers are." (Price, 2015) which comes out of the awareness that though ICT in education may cause change at an accelerated rate, transforming the activities within the classroom depends on the teacher's knowledge, attitudes and behaviors. In fact, main challenges are more in the area of teacher's professional development and their multiple roles (Fig.1), rather than in technical areas.

\section{Acknowledgements}

1. The work is performed according to the Program of Development of Federal State-Funded Educational Institution of Higher Education "Financial University under the Government of the Russian Federation" for 2020.

2. The publication has been prepared with the support of the "RUDN University Program 5-100".

3. The work is performed according to the Russian Government Program of Competitive Growth of Kazan Federal University.

\section{Bibliographic references}

BERONJA, J. - KOZINA, F.L. 2017. Testing Blended Learning In The Home Economics Nutrition Module. In: Slavonic Pedagogical Studies Journal, vol. 6, n. 1, pp. 192-198. ISSN 1339-8660.

BURKLE, M. 2003. The Impact of Information and Communication Technologies on Higher Education Systems: Doctoral dissertation. Sussex: University of Sussex. ISBN 9780995786226

COLLINS, J. 2001. Good to Great: Why Some Companies Make the Leap and Others Don't. New York: Harper Collins. ISBN 0066620996.

GALUSHKIN, A.A. 2015a. Education in the field of national information security in the Russian federation and abroad. In: Journal of Computer Science, vol. 11, n. 10, pp. 988-994. ISSN: 1549-3636.

GALUSHKIN, A. 2015b. Internet in modern Russia: History of development, place and role. In: Asian Social Science, vol. 11, n. 18, pp. 305-310. ISSN: 1911-2017, eISSN: 1911-2025.

GERASIMENKO, T.L. - GRUBIN, I.V. - GULAYA, T.M. - ZHIDKOVA, O.N. ROMANOVA, S.A. 2012. Smart Technologies in Foreign Language Teaching. In: Economics, Statistics and Information Science, n. 5, pp. 9-12. ISSN: 1994-7844.

GROS, B. 2016. The design of smart educational environments. In: Smart Learning Environments, vol. 3, n. 15. Available online:

https://slejournal.springeropen.com/arti-cles/10.1186/s40561-016-0039-x ISSN: 21967091.

HUANG, R. - YANG, J. - ZHENG, L. 2013. The Components and Functions of Smart Learning Environments for Easy, Engaged and Effective Learning. International Journal for Educational Media and Technology, vol.7, n. 1, pp. 4-14. ISSN 1882-1693.

HWANG, G. J. 2014. Definition, Framework and Research Issues of Smart Learning environments. In: Smart Learning Environments, vol.1, n. 4, 562-576. ISSN: 21967091.

KIM, T. - CHO, J.Y. - LEE, B.G. 2013. Evolution to smart learning in public education: a case study of Korean public education. Berlin: Springer. ISBN 18684238 .

KLIMOVA, B. 2017. The Role of a Teacher in Foreign Language Teaching Enhanced by Information and Communication Technologies. In: Journal of Computational and Theoretical Nanoscience, vol. 23, n. 2, pp. 965-967. ISSN: 1546-1955. 
KOPER, R. 2014. Conditions for effective smart learning environments. Smart Learning Environments, n. 1, pp. 1-17. ISSN: 2196-7091.

KRALOVA, Z. - SKORVAGOVA, E. - TIRPAKOVA, A. - MARKECHOVA, D. 2017. Reducing student teachers' foreign language pronunciation anxiety through psycho-social training. In: System, vol. 65, pp. 49-60. ISSN 0346-251X

LAURILLARD, D. 2002. Rethinking University Teaching. London: Rutledge. ISBN10: 0415256798.

LIGHT, D. - PIERSON, E. 2012a. Highlighting Changes in the Classrooms of a Successful 1 to 1 Program in Rural Argentina. New York: Center for Children and Technology. ISBN 9780123749000.

LIGHT, D. - PIERSON, E. 2012b. Highlighting changes in Two Russian Schools with Successful One-To-One Laptop Programs. New York: Center for Children and Technology. ISBN 9780123749000.

LIN, Y.C. - LIU, T.C. - KINSHUK, D. 2015. Research on teachers' needs when using e-textbook in teaching. Smart Learning Environments, vol. 2, n. 1. Available online: https://doi.org/10.1186/s40561-014-0008-1. ISSN: 2196-7091.

MALINAUSKAS, R.K. 2017, Enhancing of Self-Efficacy in Teacher Education Students European Journal of Contemporary Education, vol. 6, n. 4, pp. 732-738. DOI: 10.13187/ejced.2017.4.732

MAYER, V. - SCHÖNBERGER, K. - CUKIER, K. 2013. Big data: A Revolution that will Transform how We Live, Work, and Think. Boston: Houghton Mifflin Harcourt. ISBN-10: 0544227751.

MERRILL, M.D. 2013. First principles of instruction: Identifying and designing effective, efficient and engaging instruction. San Francisco: Wiley. ISBN10: 0470900407

MUSIOŁ, M. 2017. How much "technics" is there in elementary technical education? In: Slavonic Pedagogical Studies Journal, vol. 6, n. 1, pp. 192-198. ISSN 1339-8660.

NAZAROVA, N.B. 2012. The use of SMART-technologies in foreign language learning. Available online: http://sdo.rea.ru/cde/conference/4/file.php?fileId=32

PERRY, D. 2003. Hand-held computers (PDAs) in Schools. Coventry: Becta. ISBN 1-85379-465-1

PICCIANO, A.G. 2012. The evolution of big data and learning analytics in American Higher Education. In: Journal of Asynchronous Learning Networks, vol. 16, n. 3, pp. 9-20. ISSN 1939-5256.

PRICE, J.K. 2015. Transforming learning for the smart learning environment: lessons learned from the Intel education initiatives. In: Smart Learning Environments, vol. 2, n. 16, 426-435. ISSN: 2196-7091

ROHFELD, R.W. - HIEMSTRA, R. 1995. Moderating discussions in the electronic classroom. Cresskill: Hampton Press. ISBN-10: 1572738774

SAHU, A. 2013. Teacher's active role in smart school and smart class education. Education Today. Available online: http://www.edutoday.in/2013/05/teachers-activerole-in-smart-school.html

SFARD, A. 1998. On two Metaphors for Learning and the Dangers of Choosing Just One. Educational Researcher, vol. 27, n. 2, pp. 4-13. ISSN: 0013189X.

SPECTOR, J.M. 2014. Conceptualizing the emerging field of smart learning environments. Smart Learning Environments, vol. 1, n. 2, pp. 562-571. ISSN: 21967091.

TYUNNIKOV, Y.S. 2017, Classification of Innovation Objectives set for Continuing Professional Teacher Development. European Journal of Contemporary Education, vol. 6 n. 1: pp. 167-181. DOI: 10.13187/ejced.2017.1.167

ZHU, Z.T. - YU, M.H. - RIEZEBOS, P. 2016. A research framework of smart education. Smart Learning Environments, vol. 3, n. 1, pp. 1-17. ISSN: 2196-7091.

XLinguae, Volume 11, Issue 2, April 2018, ISSN 1337-8384, eISSN 2453-711X 
ULICNA, K. - PISOVA, M. - HANUSOVA, S. - JANIKOVA, V. - NAJVAR, P. 2016. Expert Teacher: Objective determinants of developing and maintaining expertise. In: XLinguae, vol. 9, n. 1, pp. 91-109. ISSN 1337-8384.

Words: 4104

Characters: 28620 (15,9 standard pages)

Assoc. Prof. Dinara G. Vasbieva, PhD

Department of Foreign Languages

Financial University under the Government of the Russian Federation

Leningradsky prospect 49

125993 Moscow

Russia

dinara-va@list.ru

Assoc. Prof. Natalia L. Sokolova, PhD in Philology

Head of the Institute of Foreign Languages

RUDN University (Peoples' Friendship University of Russia)

6 Miklukho-Malkaya Str.

117198, Moscow

Russia

oushkate@mail.ru

Prof. Alfiya R. Masalimova, Dr. of Education,

Institute of Psychology and Education

Kazan (Volga region) Federal University

18 Kremlyovskaya Str.

420008 Kazan

Russia

alfkazan@mail.ru

Assoc. Prof. Vladimir M. Shinkaruk, PhD in Law

Department of Criminal Procedure and Criminalistics

Volgograd State University

100 Prospect Universitetsky

400062, Volgograd

Russia

shinkarukvm@gmail.com

Assoc. Prof. Yuliya L. Kiva-Khamzina, PhD in Philosophy

Department of Law and Cultural Studies

Nosov Magnitogorsk State Technical University

38 Lenin Prospect

455000, Magnitogorsk

Russia

Russiakiva_hamzina@mail.ru 